\title{
The Larvæ of the Plymouth Galatheidæ. II. Galathea squamifera and Galathea intermedia.
}

\author{
By \\ Marie V. Lebour, D.Sc., \\ Naturalist at the Plymouth Laboratory.
}

With one Figure in the Text and Plate I.

IN a previous paper (Lebour, 1930) the general characters of the larvæ of Galathea were described and the various stages of Galathea strigosa and Galathea dispersa identified. The present paper deals with the larvæ of Galathea squamifera and Galathea intermedia which have also been followed through their life histories. This completes the larvæ of the Galatheidæ from Plymouth with the exception of Galathea nexa, the larvæ of which have not been seen. As is noted in the previous paper this Galathea is regarded as a separate species from $G$. dispersa.

The four Galathea larvæ now known are quite easily distinguishable from one another; firstly, by their size, G. strigosa being the largest, $G$. dispersa next, $G$. squamifera smaller still, and $G$. intermedia the smallest of all; secondly, by their colour, notes of which are given below for the two last, those of the two first having already been described ; thirdly, by their abdominal spines, G. squamifera having them on the fourth and fifth segments, but much smaller than in G. strigosa, and $G$. intermedia having them on the fifth segment only as in $G$. dispersa, but the size and colour of the little larva make it unmistakable.

The two larvæ dealt with in this paper have already been partly described by Sars (1900) who takes all the species together, figuring certain stages, but it is not easy to distinguish the two from his figures. Webb (1921) also figures the first larva of $G$. squamifera.

Galathea squamifera is the common inshore form and is usually to be found between tide marks under stones. The larvæ are common inshore, sometimes but rarely, outside, in spring and summer and less commonly in autumn and winter. Females in berry from February onwards. Galathea intermedia is not so common, occurring in the Sound and outside on the Mewstone and Eddystone grounds. Larvæ both inside and outside, not so common as $G$. squamifera, chiefly in spring and summer and usually outside the Sound. 
Galathea squamifera Leach.

(Plate I, Figs. A-E.)

Four larval stages (no fifth seen), the fourth changing to a young Galathea. First larva from egg, second from first, third from second from plankton, fourth from third from plankton, young Galathea from fourth from plankton. Eggs $0.52 \mathrm{~mm}$. by $0.48 \mathrm{~mm}$. when about half-way to hatching, $0.56 \mathrm{~mm}$. by $0.64 \mathrm{~mm}$. when ready to hatch. At first orangered, then brownish. Embryonic cuticle like that of Munida with seven long spines on the telson, the antenna with eight spines, the antennule with four (Text-fig. 1, A-C).

Larvæ very transparent, but with much orange-red on the thorax,

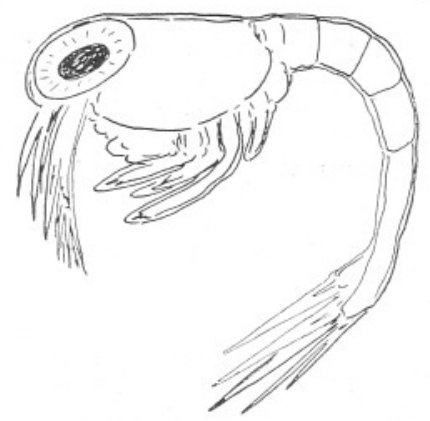

A

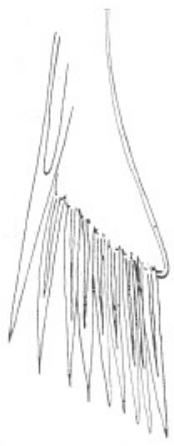

B

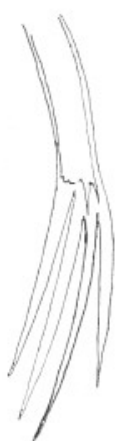

C

TEXT-Fig. 1.-A, prezoea of Galathea squamifera.

$\mathrm{B}$, antenna of same.

$\mathrm{C}$, antennule of same.

first and fifth abdominal segments (sometimes on the second), on the maxillipedes, antennular peduncle (sometimes absent), in front of the eyes (sometimes absent) and at the base of the telson (later this colour is at the hind end of the sixth abdominal segment). Usually, but not always, there is dark brown pigment in three masses at the base of the telson; in later stages these are on the sixth abdominal segment, above the red. The brown is in the form of three chromatophores which may be contracted or spread out into masses, one behind the other, two of which are on a level in front of it. These brown chromatophores are usually found in the young stages as well as in the later stages, but cases have been seen when they were absent. In the later stages there is more brown, especially above the thorax, and the fourth spine on the telson (the longest) usually has brown pigment at the base. This is the only species at 
Plymouth which has the brown pigment to any extent. The red on the fifth and sixth abdominal segments tends to be crimson. There may be yellow in the thoracic region in the later stages. Length of first larva ca. $2 \cdot 2$ to $2 \cdot 5 \mathrm{~mm}$., second larva $c a .3 \cdot 2 \mathrm{~mm}$., third larva $c a .4 \mathrm{~mm}$., fourth larva $c a .4 .8 \mathrm{~mm}$. The rostrum is moderately long with spicules, but not so long as in G. strigosa. The carapace spines and spines on the antennal scales are also shorter. The fourth abdominal segment has a pair of very short lateral spines and the fifth a pair of short spines rather longer than those on the fourth. In both they are much smaller than in G. strigosa. Denticulations occur on the hind margin of the second to the fifth abdominal segments, becoming smaller in the later stages. The telson is not so wide as in $G$. strigosa. In the last (fourth) stage there are five or six spines on the inner uropods. The young Galathea which emerged from the fourth larva was very like that of $G$. strigosa and $G$. dispersa, with long rostrum armed with five teeth each side and five principal teeth on the side of the carapace with additional smaller teeth between or behind. The colour of the first young stage is reddish, but with the casting of its skin it is brownish with a distinct white mark on the first legs.

\section{Galathea intermedia Lilljeborg.}

(Plate I, Figs. F-J.)

Larvæ partly described by Sars (1900) who figures the last stage and the first young stage. This is much the smallest of all the Galathea larvæ and also the brightest coloured.

Four larval stages (no fifth seen), the fourth changing to a young Galathea. First larva from egg, second not seen, third from plankton, fourth (last) from third from plankton, young stage from fourth from plankton. Eggs $0.4 \mathrm{~mm}$. by $0.32 \mathrm{~mm}$. when about three-parts towards hatching, $0.48 \mathrm{~mm}$. by $0.4 \mathrm{~mm}$. when ready to hatch. At first orange-red, then brownish.

Larvæ very transparent, but very brightly coloured. The only Galathea larva known to have orange-red pigment at the outer corners of the telson. Orange-red on the thorax with bright yellow, orange-red on the antennular base, on the second and fourth abdominal segments (on the fourth turning to crimson) and crimson-red at the base of the telson (in later stages on the sixth abdominal segment. An orange-red chromatophore at each corner of the telson at its outer angles. Yellow on the thorax and over the eyes.

Length of first larva $c a .2 \mathrm{~mm}$. or less, second not seen, third $c a .2 \cdot 8$ to $3.6 \mathrm{~mm}$. (varying in size considerably), fourth ca. $3.8 \mathrm{~mm}$. The rostral spine is comparatively short, not always pronouncedly prickly, the carapace spines and spines on the antennal scales and uropods are also 
short. Usually there are no lateral spines on the fourth abdominal segment but traces of them may sometimes be seen in the first stage. A pair of short lateral spines on the fifth segment. The outer uropods in the last stage with 7 spines. The first young stage is much like those of the other three species but slightly smaller. It has a fairly long rostrum with three principal teeth and two smaller each side and five lateral teeth on the carapace with one or two smaller intermediate teeth. Behind the rostrum are the characteristic two spines of the adult. The young Galathea is a brilliantly speckled orange-red with bright blue lines in the second stage.

It is now possible to make a key of the larvæ of the Plymouth Galatheidæ :-

I. Antennal scale aciculate: two dorsal spines on the abdominal segments 3, 4, and 5-(Munida).

II. Antennal scale fairly broad, small denticulations on the abdominal segments 3,4 , and 5-(Galathea).

A. Spines on fourth and fifth abdominal segments.

a. larvæ large, first larva $c a .3 .5 \mathrm{~mm}$., rostrum long, smooth, abdominal spines large-Galathea strigosa.

b. larvæ of moderate size, first larva ca. $2 \cdot 2-2 \cdot 5 \mathrm{~mm}$., rostrum fairly long, prickly, abdominal spines of moderate size-Galathea squamifera.

B. Spines on fifth abdominal segment only.

a. larvæ of moderate size, first larva $c a \cdot 2 \cdot 6 \mathrm{~mm}$., last larva $c a .5$ to $6.5 \mathrm{~mm}$. (fourth and fifth). No pigment on angles of telson-Galathea dispersa.

b. larvæ small, first larva $c a .2 \mathrm{~mm}$. or less, last larva ca. $3.8 \mathrm{~mm}$. Orange-red pigment on angles of telson-Galathea intermedia.

\section{PLATE I.}

FIg. A. Galathea squamifera from egg, $2 \cdot 2 \mathrm{~mm}$. long.

\begin{tabular}{|c|c|c|}
\hline B. & , & second larva from first from plankton, $3.2 \mathrm{~mm}$. long. \\
\hline C. & & third larva from second from plankton, $4 \mathrm{~mm}$. long. \\
\hline & & fourth larva from third from plankton, $4.8 \mathrm{~mm}$. long \\
\hline & , , & carapace of first juv. from fourth larva. \\
\hline \multicolumn{3}{|c|}{ Galathea intermedia from egg, $2 \mathrm{~mm}$. long. } \\
\hline . $\quad$, & , & third larva from plankton, $2.8 \mathrm{~mm}$. long. \\
\hline ", & , & fourth larva from third from plankton, $3.8 \mathrm{~mm}$. lon \\
\hline , & , & carapace of first juv. from fourth larva. \\
\hline
\end{tabular}


PLATE I.

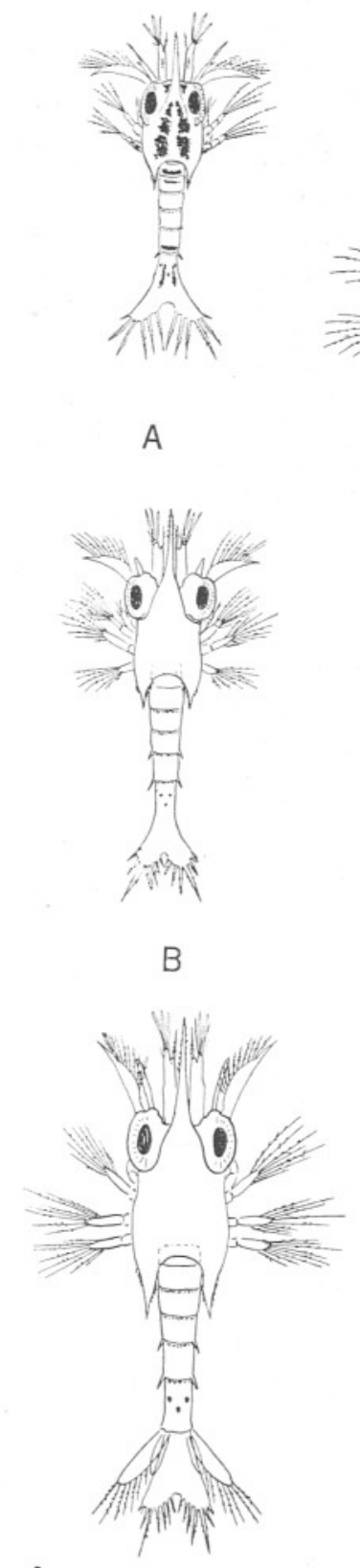

M
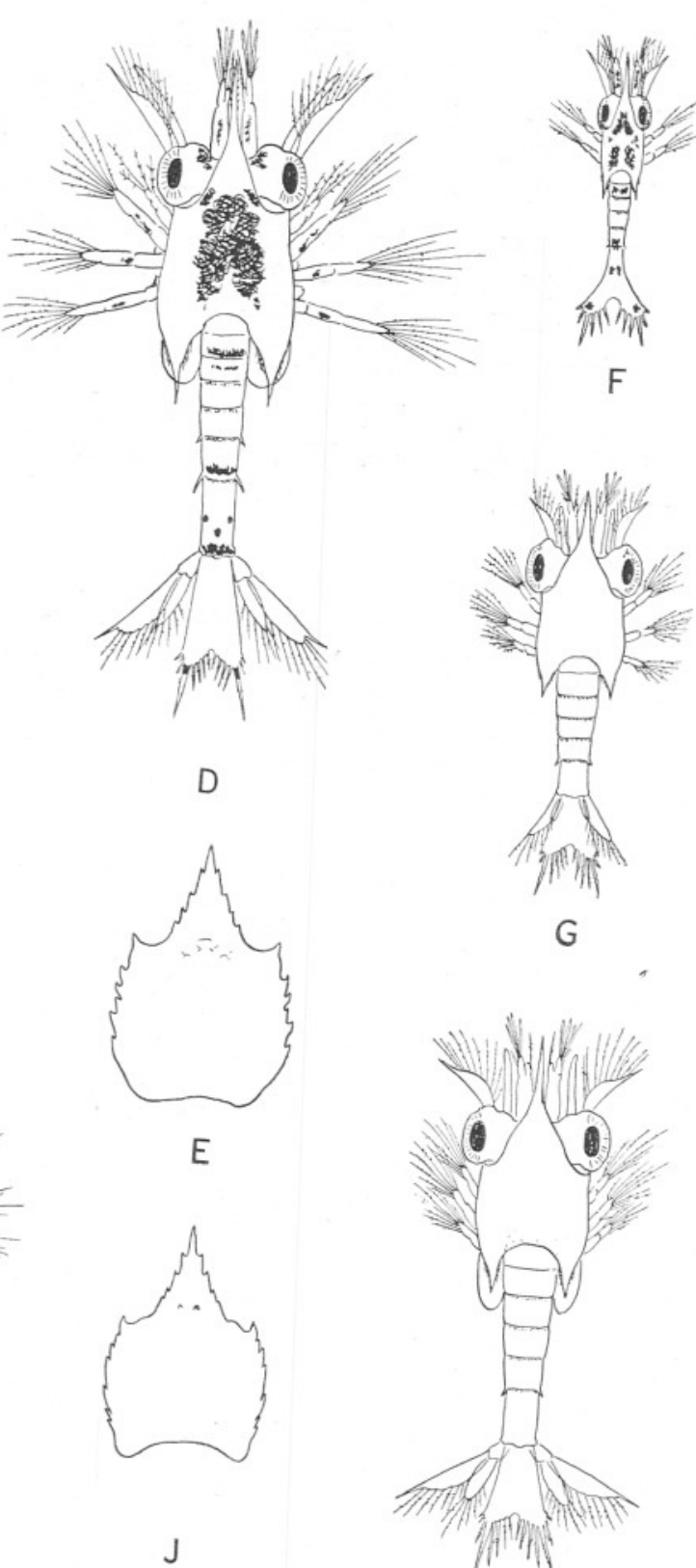

C

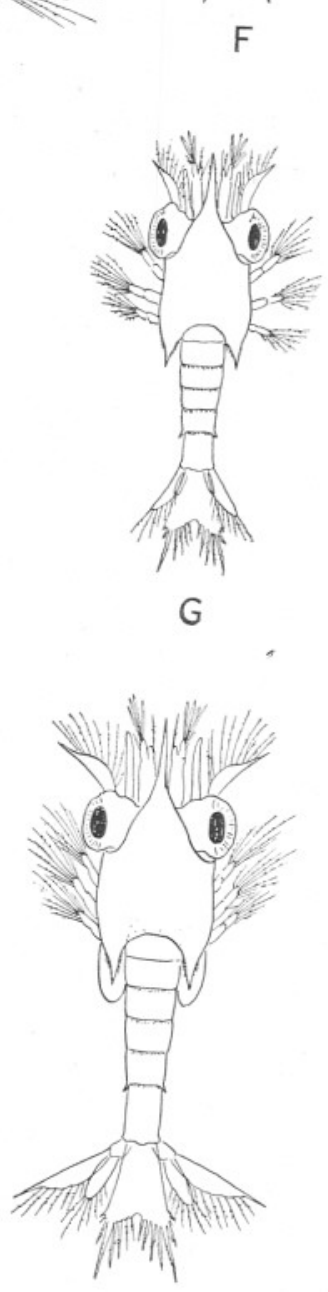

H

NEW SERIES.-VOL. XVII. NO. 2. JUNE, 1931. 


\section{LITERATURE.}

Lebour, M. V. 1930. The Larvæ of the Plymouth Galatheidæ. I. Munida banffica, Galathea strigosa, and Galathea dispersa. Jour. Mar. Biol. Assoc., N.S., Vol. XVII, No. 1, pp. 175-181.

Sars, G. O. 1890. Bidrag til Kundsknaben om Decapodernes Forvandlenger. II. Lithodes-Eupagurus-Spiropagurus-GalathodesGalathea-Munida-Porcellana-(Nephrops). Archiv. for Mathematik og Naturvidenskab., Bd. 13, 1889-90, pp. 132-201.

WebB, G. E. 1921. The Larvæ of the Decapoda Macrura and Anomura of Plymouth. Jour. Mar. Biol. Assoc., N.S., Vol. XII, No. 3, pp. 385-417. 